\title{
Cambium non est mutuum: exchange and interest rates in medieval Europe
}

Article

Accepted Version

Bell, A. R., Brooks, C. and Moore, T. K. (2017) Cambium non est mutuum: exchange and interest rates in medieval Europe. The Economic History Review, 70 (2). pp. 373-396. ISSN 1468-0289 doi: https://doi.org/10.1111/ehr.12374 Available at https://centaur.reading.ac.uk/57199/

It is advisable to refer to the publisher's version if you intend to cite from the work. See Guidance on citing.

To link to this article DOI: http://dx.doi.org/10.1111/ehr.12374

Publisher: Wiley-Blackwell

All outputs in CentAUR are protected by Intellectual Property Rights law, including copyright law. Copyright and IPR is retained by the creators or other copyright holders. Terms and conditions for use of this material are defined in the End User Agreement.

\section{www.reading.ac.uk/centaur}

\section{CentAUR}

Central Archive at the University of Reading

Reading's research outputs online 


\title{
Cambium non est mutuum: exchange and interest rates in medieval Europe*
}

\author{
Adrian R. Bell, ICMA Centre, Henley Business School, University of Reading \\ Chris Brooks, ICMA Centre, Henley Business School, University of Reading \\ Tony K. Moore, ICMA Centre, Henley Business School, University of Reading
}

\begin{abstract}
A major gap in our understanding of the medieval economy concerns interest rates, especially relating to commercial credit. Although direct evidence about interest rates is scattered and anecdotal, there is much more surviving information about exchange rates. Since both contemporaries and historians have suggested that exchange and rechange transactions could be used to disguise the charging of interest in order to circumvent the usury prohibition, it should be possible to back out the interest rates from exchange rates. The following analysis is based on a new dataset of medieval exchange rates collected from commercial correspondence in the archive of Francesco di Marco Datini of Prato, c.1383-1411. It demonstrates that the time value of money was consistently incorporated into market exchange rates. Moreover, these implicit interest rates are broadly comparable to those received from other types of commercial loan and investment. Although on average profitable, the return on any individual exchange and rechange transaction did involve a degree of uncertainty that may have justified their non-usurious nature. However, there were also practical reasons why medieval merchants may have used foreign exchange transactions as a means of extending credit.
\end{abstract}

\footnotetext{
* This research was funded by the Leverhulme Trust (grant number RPG-193). We would like to thank Francesco Bettarini and Helen Bradley for their assistance in collecting the exchange rate data.
} 
Today, interest rates are one of the most important economic variables. Ready access to credit at low rates for businesses, consumers and governments has facilitated business investment, consumption, property ownership and a high standard of living, as well as large and countercyclical governmental expenditure, while the management of base interest rates by governments or central banks is a key tool of macro-economic policy. The medieval world, by contrast, has been seen as a period of restricted access to credit and high interest rates, discouraging investment and reducing the potential for economic growth, partly in response to the religious prohibition against usury. The idea that credit was unknown in the middle ages was challenged as long as ago as the 1920s by Postan and more recent work has presented evidence of considerable financial innovation and widespread use of credit even in rural areas. ${ }^{2} \mathrm{~A}$ better understanding about interest rates can also contribute greatly to our knowledge of medieval financial and economic development by facilitating the application of modern ideas and models.

Unfortunately, direct evidence about the interest rates actually charged in the middle ages is hard to find, as can been seen from the very short chapters on the medieval period in the standard history of interest rates by Homer and Sylla - which have not been updated since the first edition was published in $1963 .^{3}$ This too may be a result of the usury prohibition, which encouraged 'financial engineering' to construct products that hid or disguised interest charges. The problem is that, by design, such charges are either invisible in the surviving records or difficult to convert into standardised interest rates. Even where it is possible to calculate interest rates for particular transactions ex post, these can vary dramatically based on idiosyncratic factors, such as the type of transaction, the 'credit rating' of the borrower or the condition of the money market at the time of the loan, making it hard to generalise about medieval interest rates. ${ }^{4}$

The best-known evidence for medieval interest rates comes from government borrowing, and especially the long-term public debt issued by Italian and Northern European city-states. Less is known about the interest rates charged on short-term loans to monarchs. ${ }^{5}$ There is also some information about consumer loans from pawnshops or Jewish lenders, who operated under official licence and whose maximum rates were often fixed by law. ${ }^{6}$ While clearly government debt and consumer credit were important, perhaps a more significant question for the growth prospects of the medieval economy concerns the interest rates charged for commercial credit. It has been argued that the most sophisticated method used by merchants to disguise the charging of interest when extending credit was based on foreign exchange (hereafter FX) transactions and bills of exchange. ${ }^{7}$ While the theological basis for this exemption has been discussed in depth, there has been surprisingly little quantitative work using this source.

\footnotetext{
${ }^{2}$ Postan, 'Credit', pp. 234-8; Fratianni and Spinelli,'Italian city-states'; Bell et al., English Wool Market; Bell and Sutcliffe, 'Valuing medieval annuities'; Briggs, Credit and Village Society.

${ }^{3}$ Homer and Sylla, Interest Rates, pp. 87-109.

${ }^{4}$ See the methodology developed in Bell et al., 'Interest', pp. 420-2.

${ }^{5}$ Epstein, Freedom, pp. 16-29; Pezzolo, 'Bonds'; Zuijverduihn, Medieval Capital Markets; Stasavage, States of Credit; Chilosi, 'Risky institutions'.

${ }^{6}$ De Roover, Money, Banking and Credit, p. 105.

${ }^{7}$ For recent overviews from an economic history perspective, see Koyama, 'Taint'; Rubin, 'Bills of exchange'.
} 
This paper will show how the relatively voluminous surviving records about exchange rates in the middle ages can help to illuminate the much murkier question of medieval interest rates. The first section sets out how the medieval FX market operated and why FX transactions may have been able to circumvent the letter of the usury prohibition. The second introduces the primary source material, a new dataset of medieval exchange rates collected from business letters in the archive of Francesco di Marco Datini. The third explains the methodology used to calculate implicit interest rates from the spread between exchange rates as quoted in different financial centres, adjusted for the time taken to transfer funds between them. The fourth section discusses the estimated interest rates and compares them against the evidence for the rates charged on other types of loan. Finally, the fifth section will investigate the level of risk involved in FX transactions and whether it was sufficient to absolve them from the charge of usury.

\section{I.}

The sheer scale of the modern FX market may be unprecedented, but its origins can be traced back at least to medieval Europe. ${ }^{8}$ The rise of kingdoms and principalities (many of which would form the basis for today's nation-states), each asserting a monopoly on minting coins within its territory, combined with the 'Commercial Revolution' of the thirteenth century, led to an increase in cross-border trade and thus the need for FX. This was carried out on a local scale by money-changers and on an international level by (mainly Italian) merchant societies. The significance of FX was even recognised in medieval literature, with Chaucer writing of his archetypal merchant, 'wel coude he in eschaunge sheeldes selle'.

The basic principles behind the medieval exchange rate system were set out by de Roover in a series of seminal monographs and articles. ${ }^{10}$ Subsequently, Mandich made some important adjustments to the de Roover thesis, notably clarifying the interlinked nature of the market for bills of exchange, bullion and credit. ${ }^{11}$ The classic FX instrument was the bill of exchange, an informal holograph 'order to pay'. In its fullest form, the bill stated that the seller (usually known as the taker or drawer) of the bill had received a sum of money in the local currency from the buyer (the giver or remitter) at place A. The seller then ordered his correspondent (the payer or drawee) in place B to pay the equivalent value in the foreign currency, at a specified exchange rate, to the buyer's correspondent (the payee).

There was always a time lag between the issue of a bill of exchange and its settlement, as the bill had to be physically transported between the two financial centres. In general, the greater the distance between the two places, the longer the communication time. In addition, most exchange transactions had standardised maturities (known as the usance period), roughly varying with the distance. The shortest was between Florence and Pisa, where bills were payable three days after they were presented for payment. The longest was between London and the Italian cities, where bills matured three months after they were issued or drawn. Notably, usance was always longer than the communication time. This gave

\footnotetext{
${ }^{8}$ Einzig, History, pp. 71-4.

${ }^{9}$ General prologue, line 278 (Benson, ed., Riverside Chaucer, p. 28).

${ }^{10}$ See the reference list for his key works.

${ }^{11}$ Mandich, 'Ricostruzione'. The most accessible discussion incorporating de Roover and Mandich's work can be found in Mueller, Venetian Money Market, pp. 293-307
} 
the payer time to raise the funds after accepting the bill but it could also be used to create loans of varying lengths.

This time element meant that every bill of exchange necessarily involved the extension of credit. ${ }^{12}$ The seller of a bill of exchange was effectively a borrower, and the buyer a lender. In order for the bill of exchange to function effectively as a credit instrument, however, there needed to be some way of compensating the lender for the time value of their money - i.e. of paying interest. In effect, this was incorporated into the exchange rates at places A and B. This helps to explain one of the key features of medieval exchange rates, which may appear peculiar to modern eyes, namely that the same currency pair was quoted at different rates at each end of the transaction, with the local currency almost always valued more highly than the foreign. As later scholastic authors put it, 'absent money, which is worth less, is being bought or exchanged for present money, which is worth more'. ${ }^{13}$ The existence of this differential has been demonstrated empirically by de Roover for Barcelona and Bruges, Bolton and Guidi Bruscoli for Bruges and Venice, and Mueller for Venice with Barcelona, Bruges, Florence and London. ${ }^{14}$

Every FX transaction thus incorporated the time value of money into a premium or discount on the exchange rates charged. The use of bills of exchange as pure credit instruments required not one transaction but two. The first was the outgoing bill of exchange. The second was a rechange operation by which the value payable was returned back to the place of origin. The buyer of a bill of exchange's profits resulted from the differential between the exchange rate at place $\mathrm{A}$ when the bill was originated and the exchange rate at place B when the bill was rechanged. Since this involved two exchange transactions, the term of the loan was equal to the sum of the usance periods from city A to city B and back from city B to city A. It should be noted that, even in the case of a 'genuine' trade bill intended to transfer funds from one place to another, the buyer of the bill would still benefit by receiving more foreign currency in place B relative to the local currency that he had paid in place A.

This can be illustrated by a practical example. On 26 September 1442 in Venice, Francesco Venier and brothers received 150 ducats from Cosimo de'Medici and company, payable in London at usance (three months) at the rate of $441 / 2$ pence sterling per ducat. Both Venier and Cosimo shared a correspondent in London, Uberto de'Medici, and so £27 13s 3d sterling should have been debited from Venier's account and credited to Cosimo's. On 31 December, however, Venier defaulted and so the bill was 'protested' and sent back to Venice. Importantly, this rechange bill was drawn at the exchange rate current in London, namely $41 \frac{1 / 4}{4}$ pence per ducat. ${ }^{15}$ Therefore, when this second bill came due in Venice circa 31 March 1443, Venier owed Cosimo 161 ducats 16 soldi and 4 denari - an increase of $7.9 \%$. Alternatively, the spread between the exchange rate in Venice and in London was 31/4 pence per ducat (also 7.9\%). Since the two transactions took six months, this was equivalent to an annualised interest rate of $15.8 \%$ (non-compounded) or $16.4 \%$ (compounded). Now, it is not clear whether Venier was unable to honour the bill for legitimate business reasons or if Cosimo had agreed in advance that the bill would be protested and Venier would repay him in Venice. The latter would be an example of the use of FX transactions to construct a loan and

\footnotetext{
${ }^{12}$ De Roover, Rise and Decline, p. 109.

${ }^{13}$ Quoted in d'Emic, Justice, p. 216.

${ }^{14}$ See the graphs in de Roover, Bruges Money Market, pp. 24-5; Bolton and Guidi Bruscoli,

'Borromei', pp. 472-4; Mueller, Venetian Money Market, pp. 319, 321, 328, 334-5, 603, 607-8.

${ }^{15}$ Calendar of State Papers Venice, p. 568.
} 
the former of a 'genuine' trade bill but the implicit interest rate would be the same regardless of the intention of the parties.

One factor affecting this differential between the exchange rates quoted at opposite ends of a currency pair was therefore the time value of money, that is, the rate of interest. This was not the only driver of exchange rate movements. De Roover identified four other factors that could influence exchange rates, namely monetary standards, the balance of trade, government intervention and speculation. ${ }^{16}$ During the period under study, there were few dramatic changes to monetary standards or instances of government intervention in the markets. ${ }^{17}$ Moreover, exchange rates (and so implicit interest rates) adjusted rapidly to such actions. The activities of speculators may have served to push the FX market back towards equilibrium. Perhaps the most significant of these factors was changes in the local demand for and supply of money in response to trade flows or economic activity - this can be seen in the seasonal patterns exhibited by exchange rates and, consequently, interest rates. ${ }^{18}$ As a result of these factors, the return on any individual transaction could vary depending on the particular circumstances of the two money markets. Conversely, this paper hypothesises that the average spread between the two exchange rates reflects the 'market' interest rate for shortterm commercial loans.

In its medieval form, usury did not refer solely to excessive rates of interest, but encompassed the exaction of anything above the principal. ${ }^{19}$ The conflict between this strict rule and economic realities led to the development of various exceptions and attempts to uncover 'loopholes'. For instance, the thirteenth-century canonist Hostiensis listed thirteen extrinsic titles that could justify the exaction of sums above the principal lent. ${ }^{20}$ These included venditio sub dubio, for sales of goods on credit where the market price was expected to change, and gratis dans, a free gift from the borrower. The latter formed the basis for the payments made on time deposits a discrezione accepted by Italian merchant societies. At least legally, the payment of interest on such deposits was purely voluntary on the part of the borrower; in practice, however, payment was essential to maintain business confidence. ${ }^{21}$ This leads to a final element of the medieval theory of usury, namely the importance of the intention behind the transaction. Regardless of the technical excuse used, if the creditor intended to receive back more than he had lent, then he was guilty of usury. Although intention was difficult to prove in court, it could be left to the confessional. ${ }^{22}$

With specific reference to FX transactions, a more technical argument held that cambium non est mutuum (an exchange is not a loan) but rather a permutatio or an emptio-

\footnotetext{
${ }^{16}$ De Roover, Bruges Money Market, pp. 37-50.

${ }^{17}$ For example, the dukes of Burgundy were notorious for their interference with the Flemish currency but the vast majority of our implicit interest rates for Bruges date from 1390 to 1410, a period of unusual monetary stability (ibid, pp. 39-41)..

${ }^{18}$ This important question is beyond the scope of the current study but, for a preliminary investigation, see Bell et al, 'Seasonality'.

${ }^{19}$ The literature on the principles behind the medieval usury laws is immense and tangled. For a reasonable introduction, see Wood, Medieval Economic Thought, pp. 159-205. More detail about contemporary theological opinions can be found in Noonan, Scholastic Analysis and, with special reference to FX, de Roover, 'Scholastics'.

${ }^{20}$ Noonan, Scholastic Analysis, pp. 101-32.

${ }^{21}$ De Roover, 'Scholastics', p. 262.

${ }^{22}$ Noonan, Scholastic Analysis, pp. 30-6.
} 
venditio since there was, in theory at least, a change of currencies involved. ${ }^{23}$ Of course, in the case of exchange and rechange, the lender was both advancing money and being repaid in the same currency. An alternative line of defence was that usury involved a certain gain but, in the transaction discussed above, the return was not fixed in advance but depended on the future movement of the exchange rate at the second centre. Some later scholastics likened it to venditio sub dubio, one of the extrinsic titles to interest. ${ }^{24}$ In the same way as the price of commodities could change over time depending on demand, the rechange rate could vary in response to the particular conditions of trade and the demand for money at the second centre. Although the existence of a spread between the exchange rates at the two financial centres meant that, on average and over the long run, the buyer/lender would receive a positive return, this could vary and, indeed, they could sometimes lose money on the transaction. Neither the lender nor the borrower in any specific exchange and rechange transaction could know the interest rate in advance and thus bills of exchange were argued not to be usurious. This paper will attempt to quantify the level of uncertainty involved in such transactions.

The use of FX transactions to conceal loans in this way was called 'dry exchange' (cambium secco) because it did not water the flows of trade. It could be carried out by actually sending a bill of exchange that was then 'protested' and returned back to the sender. A more efficient method was exchange cambium sine litteris or senza lettera. Here the FX transactions were purely book-keeping entries based on reported market rates at the second financial centre. ${ }^{25}$ This avoided the fixed costs of sending and then protesting bills of exchange; they can be seen as derivatives contracts on future exchange rates. Alternatively, there were allegations of fictitious exchanges where the exchange rates were not based on market rates but agreed in advance. However, by making profits certain, this would have fallen foul of the usury prohibition.

Of course, although the spreads between exchange rates at different financial centres clearly reflected the time value of money, this did not mean that bills of exchange were only or even primarily used to extend credit locally. In his study of the Covoni account books, Mandich found numerous examples of what he termed 'speculative exchange' ${ }^{26}$ Here the Covoni in Florence bought bills of exchange on Venice without any prior agreement with the seller to rechange that sum in Venice. Instead, once that bill was paid in Venice, they relied on their broker there to find a second counterparty, one who wanted money in Venice and could draw on funds in Florence. In this case, there was no guarantee that they would find a matching counterparty. The buyers of such bills would still have benefitted from the favourable exchange rates but would also have played a useful economic role by acting as counterparties for merchants wishing to transfer funds for trading purposes.

There is thus a debate over the extent to which bills of exchange were used as a way of disguising loans rather than actually transferring funds. Most historians have followed de Roover in asserting that bills of exchange were primarily used as credit instruments; a position shared by some contemporary theologians. Conversely, Leone has argued that speculation on exchange rates was secondary to the efficient mobilization of international capital while Bolton and Guidi Bruscoli found few protested bills or obvious examples of

\footnotetext{
${ }^{23}$ Wood, Medieval Economic Thought, p. 200.

${ }^{24}$ Noonan, Scholastic Analysis, pp. 183-7.

${ }^{25}$ For an explanation and examples, see Mueller, Venetian Money Market, pp. 318-26.

${ }^{26}$ Mandich, 'Ricostruzione', pp. clxxx-clxxxii.
} 
exchange and rechange in the account books of the Borromei at Bruges (1438) and London (1436-9). ${ }^{27}$ For our current purpose, however, the spreads between the exchange rates quoted in different cities can be used as an indication of market expectations about interest rates regardless of the intentions of the participants in particular transactions.

\section{II.}

Along with prices, there is probably more quantitative data about FX rates in the Middle Ages than any other economic variable. A good overview of the different currencies and rates can be found in Peter Spufford's Handbook of Medieval Exchange. This includes a number of different types of exchange rate: official rates set by state proclamation; accounting rates used in internal mercantile accounts; spot rates for manual exchange of coin for coin; and in bills of exchange. ${ }^{28}$ Recent research has explored the quantitative possibilities of the surviving exchange rate data to investigate the integration of financial markets, arbitrage possibilities and seasonality and structural breaks in exchange rate time series. ${ }^{29}$ Here we are only interested in exchange rates for bills of exchange, as the other types of exchange did not incorporate a time element.

Indeed, a number of previous studies have sought to calculate interest rates from bill exchange rates. A key vector was between Florence and Venice, known as cambium ad Venetias. Mandich looked at FX transactions between Florence and Venice in the books of the Covoni c.1336-1340, while de Roover did the same for a number of transactions by Lazzaro Bracci c. $1415-18 .{ }^{30} \mathrm{FX}$ transactions between Venice and the key northern European financial centres of Bruges and London in the mid-fifteenth century are discussed by de Roover, based on protested bills of exchange in the Medici archives, and Mueller, from the account books of Andrea Barbarigo. ${ }^{31}$ Such studies are based on actual FX transactions recorded as protested bills of exchange or in merchants' account books and so rely on a fairly narrow evidential base. However, as explained above, the profits from FX trading were a product of differential exchange rates at both ends of the exchange and rechange transaction. Therefore, it should be possible to reconstruct implicit or potential interest rates even where we do not have documentary evidence of actual exchange and rechange transactions, if we know the prevailing market exchange rates at both places.

Since successful FX trading involved predicting the future movements of exchange rates, the merchant who had better and more up-to-date information about exchange rates in other banking centres enjoyed an advantage over his uninformed peers. ${ }^{32}$ For this reason, when writing to their correspondents, merchants often listed the current market exchange rates at the end of their commercial letters. These rates were probably collected from the bill brokers that arranged deals in each city. ${ }^{33}$ They can be seen as forerunners of the exchange rate currents printed from the sixteenth century onwards, which ultimately developed into the

\footnotetext{
${ }^{27}$ Leone, 'Preliminary remarks', pp. 626-7; Bolton and Guidi Bruscoli, 'Borromei', pp. 473-4.

${ }^{28}$ Spufford, Handbook, pp. 1-liii.

${ }^{29}$ See respectively: Chilosi and Volckart, 'Money, States and Empire' and Kugler, 'Financial market integration'; Li, 'Bullion, bills and arbitrage', esp. pp. 34-72; Bell et al., 'Time series analysis'.

${ }^{30}$ Mandich, 'Ricostruzione', pp. ccxiv-ccxix; de Roover, 'Cambium ad Venetias'.

${ }^{31}$ De Roover, Rise and Decline, pp. 116-22; Mueller, Venetian Money Market, pp. 327-32.

${ }^{32}$ For the contents of these letters, see Melis, Aspetti, pp. 30-9.

${ }^{33}$ De Roover, Bruges Money Market, p. 29.
} 
modern financial press. ${ }^{34}$ Since merchants wrote frequently (on a weekly or even daily basis) and often had correspondents in several different financial centres, such business letters can provide a greater depth and wider range of data than relying on the more sporadic evidence of actual transactions.

Booth used such market exchange rates from the commercial correspondence in the archive of Francesco di Marco Datini to reconstruct the implied returns from FX transactions between Barcelona and Bruges. ${ }^{35}$ Datini, known as the 'merchant of Prato', was active as an international merchant and banker from c.1383 to his death in $1410 .{ }^{36}$ His branches (in capitals) and major correspondents are shown in figure 1. Although his main business interests concentrated on the western Mediterranean, with an arc of branches stretching from Tuscany, Southern France and Spain, he was in touch with correspondents in Northern Europe (Bruges, London and Paris) and Northern and Eastern Italy (Milan, Venice). Datini is still known today because of the survival of many of his business records, including 600 account books and 150,000 items of correspondence. ${ }^{37}$ These provide an unparalleled source for medieval economic and financial history.

The current paper draws on a greatly expanded dataset of exchange rates compiled from the Datini archive. We build on the existing material collected by de Roover for Barcelona and Bruges and Mueller for Venice. The bulk of our observations, however, were hand-collected from the original letters from Florence, Genoa, London, and Paris. ${ }^{38}$ Summary data for the relevant exchange rates is shown in table 1. This exchange rate data is then used to calculate implicit interest rates based on the spread between the exchange rates quoted at the two ends of a notional exchange and rechange transaction. Using this data and methodology, we can compare interest rates in seven European financial centres over a nearly thirty-year period between 1383 and 1411, broadening as well as deepening our understanding of medieval interest rates.

These medieval business letters are not easy sources to use. Just like FX traders today, the medieval merchants developed their own conventions and terminology to describe the exchange rates. In order to interpret them correctly, it is vital to understand the different ways in which exchange rates were quoted. ${ }^{39}$ There were two main methods of quotation. In the first, rates were quoted as 'uncertain for certain', that is as a variable number of units of currency A per fixed unit of currency B. In the second, rates were quoted as a percentage better or worse than par, reflecting the fact that most gold coins were based on a common model, either the florin of Florence or the ducat of Venice, and so had a similar intrinsic metallic content. Some rates, notably those for Bruges, were quoted in both ways at different places and times.

\footnotetext{
${ }^{34}$ McCusker and Gravesteijn, Beginnings.

${ }^{35}$ Booth, 'Foreign exchange profits'.

${ }^{36}$ The indispensable guide is still Melis, Aspetti. See also Origo, Merchant of Prato and the essays in Nigro, ed., Francesco di Marco Datini.

${ }^{37}$ Images of Datini's correspondence can be viewed online at http://datini.archiviodistato.prato.it/.

${ }^{38}$ The exchange rates given in the appendix to de Roover, Bruges Money Market, were rekeyed into our dataset. We extended the Bruges series by including letters sent to Florence and Genoa. Mueller's exchange rates for Venice are available in electronic form at the Medieval and Early Modern Data Bank (http://www2.scc.rutgers.edu/memdb/) but note that there are errors in the series for Barcelona. ${ }^{39}$ The following is based on three near-contemporary merchant manuals, attributed to Ricci c.1396 (Borlandi, ed., Manuale Mercantura), Uzzano c.1442 (Pagnini, ed., Della Decima, IV) and Chiarini c.1458 (Borlandi, ed., Libro di Mercatantie).
} 
Figure 1: Map of Datini's branches and key correspondents

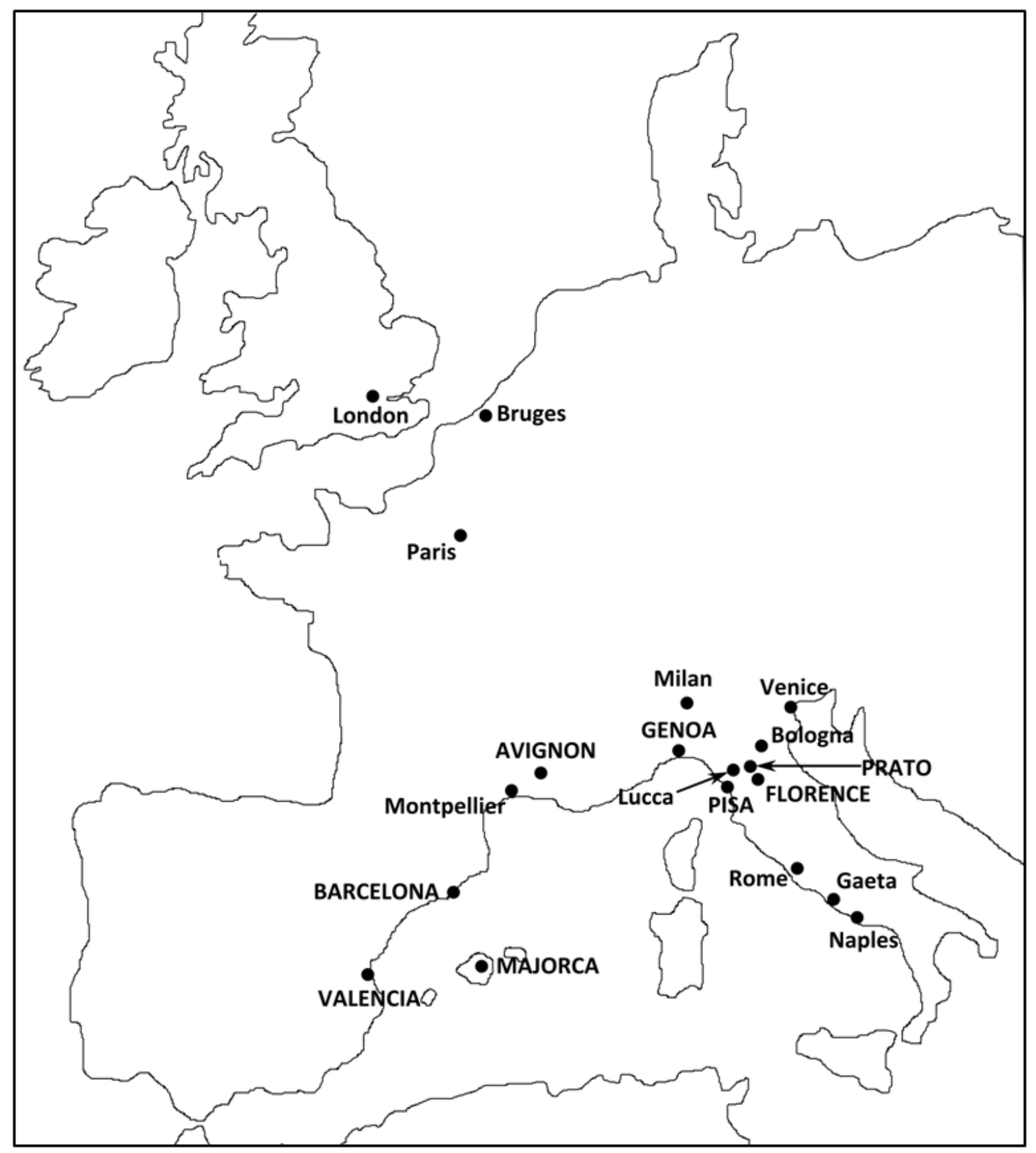


Table 1: Selected exchange rate series from the Datini archive

\begin{tabular}{|c|c|c|c|c|c|}
\hline PlaceFrom & PlaceTo & $\begin{array}{l}\text { DateRange } \\
\text { Start }\end{array}$ & $\begin{array}{l}\text { DateRange } \\
\text { End }\end{array}$ & $\begin{array}{l}\text { Daily } \\
\text { Obs }\end{array}$ & Method of quotation \\
\hline \multirow[t]{4}{*}{ Barcelona } & Bruges & $28 / 02 / 1383$ & $03 / 09 / 1411$ & 683 & $\begin{array}{l}\text { Pence of Barcelona per écu of } 22 \\
\text { groats }\end{array}$ \\
\hline & Florence & $19 / 06 / 1389$ & $03 / 09 / 1411$ & 373 & $\begin{array}{l}\text { Pence of Barcelona per florin } d i \\
\text { suggello }\end{array}$ \\
\hline & Genoa & $28 / 02 / 1383$ & $03 / 09 / 1411$ & 721 & $\begin{array}{l}\text { Pence of Barcelona per florin of } \\
25 \text { solidi }\end{array}$ \\
\hline & Venice & $17 / 03 / 1398$ & $03 / 09 / 1411$ & 337 & Pence of Barcelona per ducat \\
\hline \multirow[t]{5}{*}{ Bruges } & Barcelona & $29 / 08 / 1384$ & $08 / 06 / 1411$ & 807 & $\begin{array}{l}\text { Pence of Barcelona per écu of } 22 \\
\text { groats }\end{array}$ \\
\hline & Genoa & $29 / 08 / 1384$ & $08 / 06 / 1411$ & 820 & Groats per florin of 25 soldi \\
\hline & London & $15 / 07 / 1388$ & $08 / 06 / 1411$ & 757 & Pence sterling per écu of 24 groats \\
\hline & Paris & $29 / 08 / 1384$ & $08 / 06 / 1411$ & 806 & Groats per franc \\
\hline & Venice & $29 / 08 / 1384$ & $08 / 06 / 1411$ & 825 & Groats per ducat \\
\hline \multirow[t]{3}{*}{ Florence } & Barcelona & $05 / 02 / 1383$ & $03 / 08 / 1411$ & 1293 & Pence of Barcelona per florin \\
\hline & Genoa & $29 / 01 / 1383$ & $15 / 09 / 1410$ & 2580 & $\begin{array}{l}\text { Par between florin di suggello and } \\
\text { florin of } 25 \text { soldi }\end{array}$ \\
\hline & Venice & $29 / 01 / 1383$ & $03 / 08 / 1411$ & 2415 & $\begin{array}{l}\text { Pence affiorino per lira di grossi } \\
\text { of } 10 \text { ducats }\end{array}$ \\
\hline \multirow[t]{6}{*}{ Genoa } & Barcelona & $02 / 08 / 1382$ & $11 / 08 / 1410$ & 2581 & $\begin{array}{l}\text { Pence of Barcelona per florin of } \\
25 \text { soldi }\end{array}$ \\
\hline & Bruges & $21 / 04 / 1381$ & $11 / 08 / 1410$ & 2131 & Groats per florin of 25 soldi \\
\hline & Florence & $07 / 08 / 1379$ & $11 / 08 / 1410$ & 3355 & $\begin{array}{l}\text { Par between florin of } 25 \text { soldi and } \\
\text { florin di suggello }\end{array}$ \\
\hline & London & $23 / 10 / 1391$ & $11 / 08 / 1410$ & 1343 & $\begin{array}{l}\text { Pence sterling per florin of } 25 \\
\text { soldi }\end{array}$ \\
\hline & Paris & $02 / 08 / 1382$ & $11 / 08 / 1410$ & 1854 & $\begin{array}{l}\text { Par between florin of } 25 \text { soldi and } \\
\text { franc }\end{array}$ \\
\hline & Venice & $23 / 10 / 1379$ & $11 / 08 / 1410$ & 2234 & $\begin{array}{l}\text { Par between florin of } 25 \text { soldi and } \\
\text { ducat }\end{array}$ \\
\hline \multirow[t]{2}{*}{ London } & Bruges & $20 / 07 / 1388$ & $03 / 08 / 1411$ & 192 & Pence sterling per écu of 24 groats \\
\hline & Genoa & $06 / 01 / 1392$ & $03 / 08 / 1411$ & 186 & $\begin{array}{l}\text { Pence sterling per florin of } 25 \\
\text { soldi }\end{array}$ \\
\hline \multirow[t]{3}{*}{ Paris } & Bruges & $02 / 06 / 1384$ & $05 / 05 / 1410$ & 613 & Groats per franc \\
\hline & Genoa & $02 / 06 / 1384$ & $05 / 05 / 1410$ & 617 & $\begin{array}{l}\text { Par between franc and florin of } 25 \\
\text { soldi }\end{array}$ \\
\hline & Venice & $12 / 06 / 1384$ & $05 / 05 / 1410$ & 524 & Par between franc and ducat \\
\hline \multirow[t]{5}{*}{ Venice } & Barcelona & $27 / 02 / 1399$ & $20 / 02 / 1411$ & 473 & Pence of Barcelona per ducat \\
\hline & Bruges & $13 / 02 / 1384$ & $20 / 02 / 1411$ & 787 & $\begin{array}{l}\text { Grossi of Venice per franc of } 33 \\
\text { groats }\end{array}$ \\
\hline & Florence & $07 / 11 / 1383$ & $20 / 02 / 1411$ & 1224 & $\begin{array}{l}\text { Pence affiorino per lira di grossi } \\
\text { of } 10 \text { ducats }\end{array}$ \\
\hline & Genoa & $26 / 11 / 1383$ & $04 / 10 / 1410$ & 1031 & $\begin{array}{l}\text { Par between ducat and florin of } 25 \\
\text { soldi }\end{array}$ \\
\hline & Paris & $28 / 07 / 1388$ & $20 / 02 / 1411$ & 592 & Grossi of Venice per franc \\
\hline
\end{tabular}

Source: Exchange Rates Dataset 
For example, the exchange rate between Florence and Venice was quoted in terms of an uncertain number of lira, soldi and denari affiorino (for convoluted historical reasons, 29 soldi affiorino - and thus 348 denari - were equivalent to one Florentine florin) per one lira di grossi (equivalent to 10 Venetian ducats). During the period of the Datini letters - c.13801411 - the exchange rate moved between about 14 lira 10 soldi affiorino and 15 lira 16 soldi affiorino or 3,480 denari to 3,792 denari affiorino. Day to day rates could be quoted down to a single denaro affiorino, although they generally moved in increments of two, four or six denari. ${ }^{40}$ This is an extraordinarily precise method of quoting exchange rates, equivalent to between five and seventeen basis points. Exchange rates with Barcelona were always quoted in terms of solidi and denari of Barcelona per unit of foreign currency and with London as a variable number of pence sterling per unit of foreign currency. As de Roover pointed out (repeatedly), the logic of the time value of money meant that the exchange rate at the place that gave certain should generally be higher than the rate at the place that gave uncertain.

The second method quoted rates as a percentage better (meglio) or worse (pegio) than par. If, for example, the rate at Florence for the Genoese florin was at par, then the buyer of a bill of exchange for 100 Florentine florins in Florence would receive 100 Genoese florins in Genoa. If the rate was five better, then the same 100 Florentine florins would be worth 105 Genoese. However, if it was five worse, then the buyer would have to pay 105 Florentine florins to receive 100 Genoese - not that 100 Florentine florins would equal 95 Genoese. ${ }^{41}$ In effect, the weaker currency gave uncertain to the stronger currency. This method of quotation seems counter-intuitive but in fact it had a significant practical benefit. If the rate at Florence was five worse and that at Genoa was six better, then the merchant could quickly calculate the spread between the two rates by adding them together and dividing by the weaker rate, in the same way as above. In this case, the spread would have been $0.95 \%$. However, it raises difficulties where the exchange rates fluctuate around par and thus frequently cross over from meglio to pegio. For this reason, in our dataset we converted all par rates to an uncertain number of units of foreign currency per 100 units of local currency.

The next variable to consider is the usance period between any two financial centres, as shown in table 2. There were two distinct methods of specifying when a bill of exchange would mature. In the first, and simplest, the bill of exchange came due a set number of days after it was drawn. In the second, the bill was payable a set number of days after sight, i.e. after it was presented to the payer by the payee. This introduces a degree of unpredictability since the travel time between centres could vary. For example, Melis found that the average postal time between Bruges and Barcelona was 23 days, but the journey could be as short as 11 or as long as 48 days. ${ }^{42}$ As usance between the two cities was 30 days after sight, the length of any individual transfer could vary from 41 to 78 days, assuming that the bill was presented immediately upon arrival. In fact, many of the actual bills of exchange from Bruges to Barcelona surviving in the Datini archive record the date on which the bill was issued in

\footnotetext{
${ }^{40}$ This exchange rate was sometimes quoted as a percentage better or worse than par, where par was taken as ten lira affiorino $(3,480 \mathrm{~d})$ to one lira di grossi.

${ }^{41}$ Mueller, Venetian Money Market, pp. 589-90 unfortunately confuses this point. For the correct interpretation, see Heers, Gênes, p. 78.

${ }^{42}$ Melis, 'Intensità', pp. 197, 203.
} 
Table 2: Usance periods

\begin{tabular}{|l|l|l|l|l|l|l|l|}
\hline & Barcelona & Bruges & Florence & Genoa & London & Paris & Venice \\
\hline Barcelona & & S+30(60) & D60 & S $+20(40)$ & N/A & S+30(50) & D60 \\
\hline Bruges & S+30(60) & & N/A & D60 & D30 & D30 & D60 \\
\hline Florence & D60 & D60 & & S+8(14) & D90 & D60 & S+5(10) \\
\hline Genoa & S+20(40) & S+10(34) & S+8(14) & & D90 & S+10(28) & S+15(25) \\
\hline London & N/A & D30 & N/A & D90 & & N/A & D90 \\
\hline Paris & S+30(50) & S+10(14) & D60 & D60 & D30 & & D60 \\
\hline Venice & 60 & D60 & D20 & S+15(25) & D90 & D60 & \\
\hline
\end{tabular}

Source: Borlandi, ed., Manuale di Mercantura; Pagnini, ed., Della Decima, IV; Borlandi, ed., Libro di Mercatantie. Notes: D indicates date from drawing of the bill while S indicates days after sight (presentation of the bill). In the latter case, the number in brackets shows the average usance period taking into account the mean postal time (Melis, 'Intensità').

Bruges and subsequently accepted by the payer in Barcelona. ${ }^{43}$ From this, it appears that bills were presented on average 28 days after drawing. Moreover, a smaller number of bills fixed the usance period at 60 days from drawing. As a result, we have used 60 days as our standard duration for an FX transaction between Barcelona and Bruges, rather than the 53 days assumed by Booth. ${ }^{44}$

An interesting feature is the asymmetry in usance periods between certain centres depending on the direction of the transaction. For example, usance from Florence to Venice was five days after sight and, since the usual travel time between the two cities was five or six days, the standard usance period was 10 or 11 days. ${ }^{45}$ By contrast, usance from Venice to Florence was 20 days after drawing. In both directions, a complete exchange and rechange transaction would take thirty days but, from Florence, the rechange rate (and thus the implicit interest rate) would be fixed after 10 days while, from Venice, it would be fixed after 20 days. This affected the riskiness of the two transactions as the lender in Florence only had to predict the Venetian exchange rate 10 days ahead, while his counterpart in Venice had to wait twice as long. Clearly, the FX system was established by Florentine merchants for their own benefit. ${ }^{46}$ Similarly, usance from Genoa to Paris and Bruges was ten days after sight (plus average postal times of 18 and 24 days respectively) while that from both Bruges and Paris to Genoa was 60 days from drawing. Usance seems to have been ten days from sight from Paris to Bruges but one month from drawing from Bruges to Paris. ${ }^{47}$

\footnotetext{
${ }^{43}$ Since Datini had no branch in Bruges, we lack any bills sent from Barcelona to Bruges.

${ }^{44}$ Booth, 'Foreign exchange profits', pp. 133-5. We repeated our calculations using a usance period of 53 days; the spreads do not change appreciably (changing from $4.40 \%$ to $4.35 \%$ for Barcelona-Bruges and $4.50 \%$ to $4.48 \%$ for Bruges-Barcelona) but the annualised implicit interest rates increase in proportion to the reduction in the term (from $14.42 \%$ and $14.67 \%$ to $16.23 \%$ and $16.67 \%$ respectively).

${ }^{45}$ We take ten days - using the evidence of the exchange and rechange transactions identified by Mandich, 'Ricostruzione', from the Covoni account books.

${ }^{46}$ Mueller, Venetian Money Market, p.296 and n.10.

${ }^{47}$ There is conflicting evidence about the usance periods between Bruges and Paris. Ricci gives usance from Paris to Bruges as twelve days from sight (plus postal time of four days) but Bruges to Paris as one month from drawing. This broadly agrees with the manual attributed to Chiarini, which states that usance from Paris to Bruges was ten days from sight and Bruges to Paris was one month from drawing. According to Uzzano, however, usance was ten days from sight in both directions. The time taken for a complete change and rechange transaction could therefore be 28 or 44/46 days. We take 46 days as the
} 
The fact that there was a considerable variety in usance periods between different financial centres potentially allowed for the construction of loans of differing maturities. Exchange and rechange between two close centres, for example Florence and Venice or Florence and Genoa, produced a loan of roughly one month's duration. A longer term loan of four months could be engineered by engaging in an exchange and rechange transaction between Italy and Spain or Northern Europe and Spain. The longest loans, of six months, were between Genoa (later Venice) and London. Loans could also be extended by immediately entering into another exchange and rechange transaction; one borrower remained on the exchange for nearly two years. ${ }^{48}$ Obviously, the length of the usance periods in both directions needs to be taken into account when converting the spreads between the two exchange rates into an annualised interest rate.

\section{III.}

Our methodology draws on the basic principles set out by de Roover and Booth's idea of using market exchange rates but, instead of looking at just one currency pair, we calculate interest rates for all currency pairs where we have sufficient information in our dataset of exchange rates collected from the Datini archive. This involves a three stage process. First, we identify matching sets of exchange rate observations for each of our currency pairs. Second, we calculate the spread between these two rates, and third, we convert this spread to an annualized interest rate taking into account the usance period. To illustrate the methodology in more detail, we will take the exchange between Florence and Venice (cambium ad Venetias) as an exemplar.

Our dataset contains 2,415 daily observations of the exchange rate between the Florentine florin and the Venetian ducat at Florence and 1,224 daily observations at Venice. First, we identify all cases where we have an observation at Florence and a corresponding observation at Venice lagged by the usance period, and vice versa. Since usance from Florence to Venice was ten days, we identify all potential matches where date $_{t}$ of an exchange rate observation in Florence equals date $t_{t+10}$ for an exchange rate observation in Venice. This produces 275 matching sets of observations. Now, the usance of bills from Venice to Florence was twenty days after drawing; identifying all matches where date $t_{t}$ of an observation in Venice corresponds to an observation with date $_{t+20}$ in Florence returns 256 matches.

To enlarge the dataset, where there were no exact matches, we extended the search to include the closest match within one day before or after the exact target date. If we find a matching entry one day before and one day after the target date, we take the average of the two observations. This increases the number of observations to 832 and 769 respectively. Further expanding the parameters to include the closest date within two days of the target returns 1,276 and 947 matches. Given the relatively short usance periods between these two cities, it is not appropriate (or even necessary, given the amount of data from these two places and thus the number of matches returned by even restrictive assumptions) to extend the

Ricci manual is closest to our period but we repeated our calculations using the alternative usance period of 14 days in each direction. As in the case of Barcelona and Bruges (above, n. 43), the spreads remain similar but the annualised rates increase in line with the fall in the term.

${ }^{48}$ Mueller, Venetian Money Market, pp. 290-1 n.4. 
parameters further. For some of the more distant centres with longer usance periods or less surviving data, however, we search for matches within up to seven days of the target date. ${ }^{49}$

Second, we calculate the spread between these two rates, $S p$. When exchange rates are quoted using the 'certain'/'uncertain' method, as in this case, the spread is calculated by deducting the rate at the place that gave uncertain, $E R^{U C}$ (i.e. Florence) from that at the place that gave certain, $E R^{C}$ (Venice). This nominal spread can then be converted into a percentage value by dividing it by the rate at the place that gave uncertain. Note that this basic principle applies regardless of the direction of the transaction. ${ }^{50}$ This is shown in equation (1).

$S p=\frac{E R^{c}-E R^{u c}}{E R^{u c}}$

Where the exchange rates are quoted as a percentage better or worse than par, the method is slightly different. As explained above, our dataset converted all of these rates into the amount of foreign currency received per 100 units of local currency. In effect, both places give certain. The exchange rate at $\mathrm{A}$ thus represents the value received at place $\mathrm{B}$ in return for 100 units of currency A. This is then multiplied by the rechange rate (the exchange rate at B) to calculate the sum received back at place A. Deducting the original 100 units that we started with at A produces the nominal spread, and this can be converted into percentage format by dividing by 100. This is shown in equation (2).

$S p=\frac{\left(E R^{A} * \frac{E R^{B}}{100}\right)-100}{100}$

For purposes of comparison, we convert the percentage spread between the two rates - which represents the return from any one exchange and rechange transaction - into an annualized rate, taking into account the usance periods. In this case, even though usance from Florence to Venice differed from that from Venice to Florence, the overall time taken for a complete exchange and rechange operation was the same in both cases, namely 30 days or

\footnotetext{
${ }^{49} \mathrm{We}$ also conduct a further robustness check. In many cases, the number of daily observations at one centre is much greater than at the other. Continuing the above example, we have twice as many observations at Florence than at Venice. The search parameter will sometimes match multiple Florentine observations with the same observation at Venice. For instance, we have an observation on 27 January 1385 at Florence, with matches exactly with an observation on 6 February at Venice. However, running the search with the expanded parameters would also identify that same observation at Venice as the closest match for Florentine observations on 26 January (within one day), 24 January (three days) and 23 January (four days). To test whether this has an impact on the average and distribution of the implicit interest rates, we also construct a second set of calculations for Florence, but this time matching an observation at Venice at date $_{t}$ with one at Florence at date $e_{t-10}$. These results are shown in table 3 in brackets and do not differ markedly from those using the first method.

${ }^{50}$ In his calculations for exchange and rechange from Bruges to Venice, de Roover (Rise and Decline, p. 120) divides by the rate at Venice as the place of rechange rather than by the rate at Bruges as the place that gave uncertain. As a result, he understates the interest rates by an average of $1.58 \%$.
} 
roughly one month. We calculate both a simple annualized interest rate using equation (3) and a compounded annualized interest rate using equation (4).

$I R_{\text {simple }}=S p *\left(\frac{365}{\text { usance }_{A B}+\text { usance }_{B A}}\right)$

$I R_{\text {compounded }}=(1+S p)^{\wedge}\left(\frac{365}{\text { usance }_{A B}+\text { usance }_{B A}}\right)-1$

Summary details for cambium ad Venetias are shown in table 3. The average spread at Florence was between $0.80 \%$ and $0.84 \%$, depending on the match parameters, while in Venice it was between $0.79 \%$ and $0.82 \%$. When these are converted into annualized rates, those for Florence range from $9.76 \%$ to $10.22 \%$ (simple) and $10.59 \%$ to $11.15 \%$ (compounded), and those for Venice from $9.73 \%$ to $10.00 \%$ (simple) and $10.89 \%$ to $11.3 \%$ (compounded). Both the spreads and the annualized interest rates are very similar whether the FX transaction originated in Florence or in Venice. However, the distribution of these returns differs in significant ways. This can be seen visually in figure 2 or in the standard deviations reported in table 3. There is a markedly greater variation in the implied interest rates at Venice as compared to Florence - the standard deviation for transactions originated in Venice is 50\% higher than for those in Florence. This presumably reflects the fact that the return rate (and hence the spread) was fixed after 20 days in bills of exchange from Venice but after only 10 days in those from Florence. It may be another indication that the Florentine cambistas established this system in their own interests. We will return to the question of the risk involved in exchange and rechange transactions, and whether this was sufficient to avoid the charge of usury in section $\mathrm{V}$.

Table 3: Cambium ad Venetias example

\begin{tabular}{|l|l|l|l|l|l|l|}
\hline $\begin{array}{l}\text { Place of } \\
\text { transaction }\end{array}$ & \multicolumn{5}{|c|}{ Florence } & \multicolumn{3}{c|}{ Venice } \\
\hline $\begin{array}{l}\text { Match parameters } \\
\text { (days) }\end{array}$ & 0 & 1 & 2 & 0 & 1 & 2 \\
\hline Observations & $\begin{array}{l}275 \\
(232)\end{array}$ & $\begin{array}{l}832 \\
(612)\end{array}$ & $\begin{array}{l}1276 \\
(781)\end{array}$ & 256 & 769 & 947 \\
\hline Mean spread & $\begin{array}{l}0.80 \% \\
(0.80 \%)\end{array}$ & $\begin{array}{l}0.82 \% \\
(0.84 \%)\end{array}$ & $\begin{array}{l}0.84 \% \\
(0.84 \%)\end{array}$ & $0.80 \%$ & $0.79 \%$ & $0.82 \%$ \\
\hline $\begin{array}{l}\text { Simple annualized } \\
\text { interest rate }\end{array}$ & $\begin{array}{l}9.76 \% \\
(9.76 \%)\end{array}$ & $\begin{array}{l}10.03 \% \\
(10.23 \%)\end{array}$ & $\begin{array}{l}10.22 \% \\
(10.24 \%)\end{array}$ & $9.73 \%$ & $9.62 \%$ & $10.0 \%$ \\
\hline $\begin{array}{l}\text { Compounded } \\
\text { annualized } \\
\text { interest rate }\end{array}$ & $\begin{array}{l}10.59 \% \\
(10.21 \%)\end{array}$ & $\begin{array}{l}10.91 \% \\
(11.16 \%)\end{array}$ & $\begin{array}{l}11.15 \% \\
(11.20 \%)\end{array}$ & $10.97 \%$ & $10.89 \%$ & $11.30 \%$ \\
\hline $\begin{array}{l}\text { Standard } \\
\text { deviation of the } \\
\text { spread }\end{array}$ & $\begin{array}{l}0.71 \% \\
(0.71 \%)\end{array}$ & $\begin{array}{l}0.74 \% \\
(0.76 \%)\end{array}$ & $\begin{array}{l}0.77 \% \\
(0.78 \%)\end{array}$ & $1.02 \%$ & $1.05 \%$ & $1.05 \%$ \\
\hline
\end{tabular}

Source: Exchange Rate Dataset. Note: the figures in brackets after the Florentine results are based on the alternative method of matching observations set out above. 
Figure 2: Distribution of returns from cambium ad Venetias

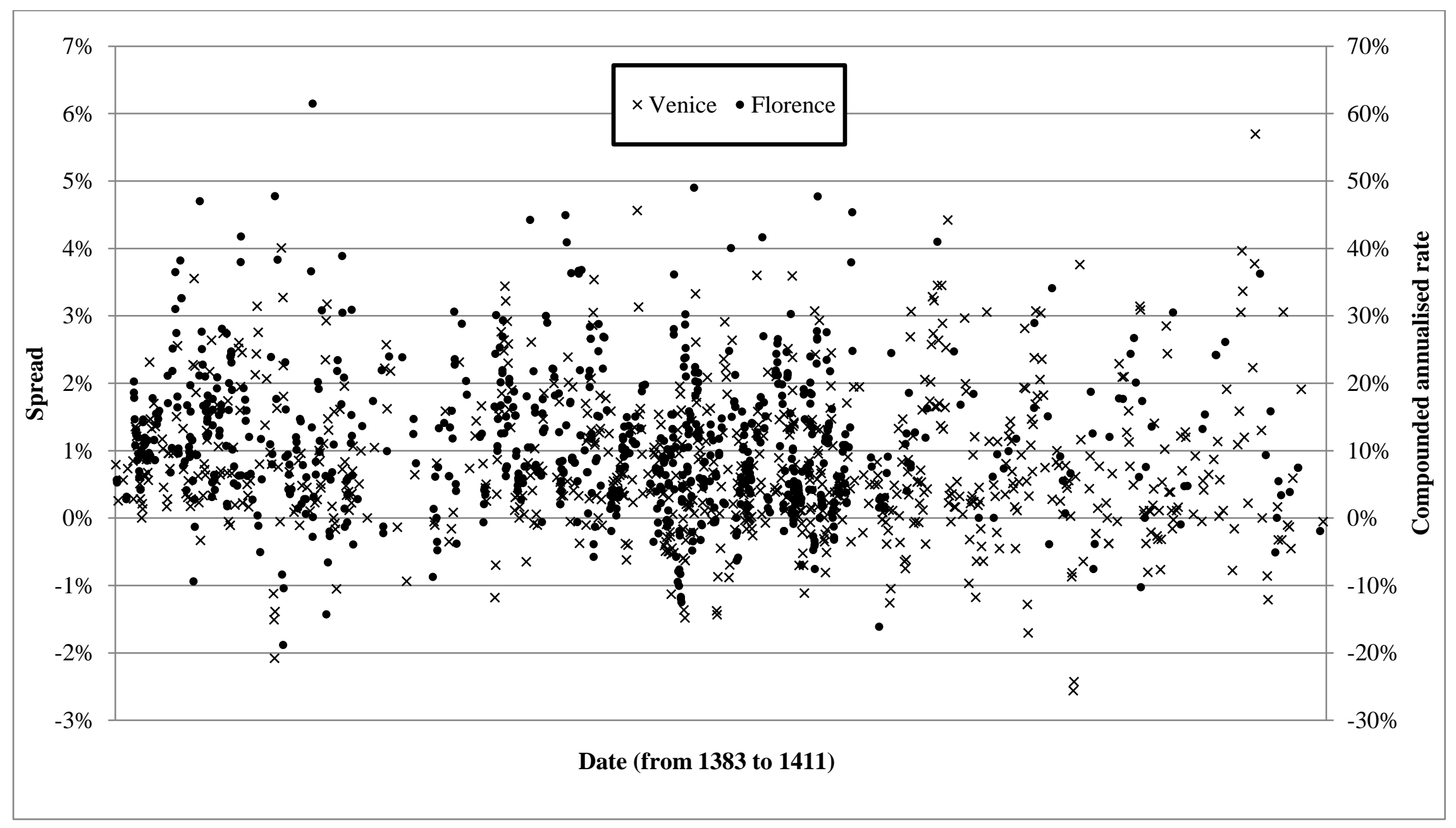


The same methodology was then applied to our other exchange rate series. Although our exchange rate database contains a total of 88 currency pairs from 10 different cities, it was not feasible to calculate interest rates for all of these. The first requirement is that we have exchange rate observations from the two centres at each end of the currency pair. For example, Florence quoted Bruges, London and Paris but none of those three places quoted rates for Florence and therefore it is not possible to calculate interest rates between those three cities and Florence using the exchange and rechange method. The second is that we have a sufficient number of observations to find a reasonable number of matching sets. As a result, our dataset has been reduced to 14 currency pairs from seven different financial centres (and thus 28 sets of implicit interest rates). The results for all our locations and currency pairs are shown in table 4 . We only report one set of matching criteria for each pair, seeking to maximize the number of matches while minimizing the range of the search parameters. Even so, our calculations are based on several hundred matching observations for each pair whereas the previous studies cited above have relied on dozens.

Table 4: Implicit interest rates from the Datini archive, 1380-1411

\begin{tabular}{|l|l|l|l|l|l|l|l|}
\hline CityFrom & CityTo & Term & Match & Number & Spread & Simple APR & Compounded APR \\
\hline Barcelona & Bruges & 120 & 4 & 337 & $4.40 \%$ & $13.39 \%$ & $14.42 \%$ \\
\hline Barcelona & Florence & 120 & 3 & 278 & $3.93 \%$ & $11.97 \%$ & $12.73 \%$ \\
\hline Barcelona & Genoa & 80 & 2 & 560 & $3.33 \%$ & $15.18 \%$ & $16.79 \%$ \\
\hline Barcelona & Venice & 120 & 3 & 245 & $4.43 \%$ & $13.47 \%$ & $14.31 \%$ \\
\hline Bruges & Barcelona & 120 & 4 & 459 & $4.50 \%$ & $13.70 \%$ & $14.67 \%$ \\
\hline Bruges & Genoa & 94 & 1 & 466 & $3.73 \%$ & $14.49 \%$ & $15.93 \%$ \\
\hline Bruges & London & 60 & 4 & 179 & $2.24 \%$ & $13.66 \%$ & $15.20 \%$ \\
\hline Bruges & Paris & 46 & 1 & 194 & $1.33 \%$ & $11.55 \%$ & $11.53 \%$ \\
\hline Bruges & Venice & 120 & 3 & 500 & $3.68 \%$ & $11.18 \%$ & $11.82 \%$ \\
\hline Florence & Barcelona & 120 & 3 & 393 & $3.85 \%$ & $11.70 \%$ & $12.37 \%$ \\
\hline Florence & Genoa & 28 & 0 & 880 & $0.83 \%$ & $10.83 \%$ & $12.10 \%$ \\
\hline Florence & Venice & 30 & 1 & 832 & $0.82 \%$ & $10.03 \%$ & $10.91 \%$ \\
\hline Genoa & Barcelona & 80 & 2 & 543 & $3.48 \%$ & $15.89 \%$ & $17.59 \%$ \\
\hline Genoa & Bruges & 94 & 1 & 558 & $3.52 \%$ & $13.67 \%$ & $14.67 \%$ \\
\hline Genoa & Florence & 28 & 0 & 880 & $0.84 \%$ & $10.92 \%$ & $12.17 \%$ \\
\hline Genoa & London & 180 & 4 & 356 & $6.85 \%$ & $13.89 \%$ & $14.54 \%$ \\
\hline Genoa & Paris & 88 & 2 & 510 & $3.81 \%$ & $15.82 \%$ & $17.05 \%$ \\
\hline Genoa & Venice & 50 & 0 & 269 & $1.45 \%$ & $10.56 \%$ & $11.44 \%$ \\
\hline London & Bruges & 60 & 4 & 127 & $2.11 \%$ & $12.82 \%$ & $14.30 \%$ \\
\hline London & Genoa & 180 & 4 & 166 & $6.67 \%$ & $13.52 \%$ & $14.20 \%$ \\
\hline Paris & Bruges & 46 & 1 & 190 & $1.15 \%$ & $9.09 \%$ & $9.72 \%$ \\
\hline Paris & Genoa & 88 & 2 & 446 & $3.39 \%$ & $14.07 \%$ & $15.37 \%$ \\
\hline Paris & Venice & 120 & 3 & 288 & $4.26 \%$ & $12.96 \%$ & $13.77 \%$ \\
\hline Venice & Barcelona & 120 & 3 & 243 & $4.28 \%$ & $13.01 \%$ & $13.81 \%$ \\
\hline Venice & Bruges & 120 & 3 & 375 & $3.38 \%$ & $10.27 \%$ & $10.85 \%$ \\
\hline Venice & Florence & 30 & 1 & 769 & $0.79 \%$ & $9.62 \%$ & $10.89 \%$ \\
\hline Venice & Genoa & 50 & 0 & 258 & $1.32 \%$ & $9.62 \%$ & $10.78 \%$ \\
\hline Venice & Paris & 120 & 3 & 248 & $4.14 \%$ & $12.58 \%$ & $13.34 \%$ \\
\hline Souce: & & & & & \\
\hline
\end{tabular}

Source: Exchange Rate Dataset. 
IV.

At first glance, the spreads between the currency pairs seem to differ widely, from around $0.8 \%$ between Florence, Genoa and Venice all the way up to nearly $7 \%$ from Genoa to London. However, once these are annualized taking into account the different usance periods, as explained above, they fall into a much more consistent band ranging between $10 \%$ and $16 \%$. The consistency of these results between the different currency pairs and financial centres is striking and confirms that the time value of money was indeed incorporated into the spread between exchange rates at different centres in a systematic way.

Moreover, the implicit interest rates calculated from exchange rates are economically reasonable and broadly comparable with other indications of the cost of commercial credit at this time. The interest rates paid by merchant companies on time deposits a discrezione at Florence varied between $6 \%$ and $10 \%$ during the later middle ages. ${ }^{51}$ Loans to private individuals were more expensive; in fifteenth-century Florence, Guiliano de'Medici charged 10-12\% per annum on six month business loans that were mostly fully-collateralised either by shares in the public debt or by third-party guarantors. ${ }^{52}$ We have seen that cambium ad Venetias returned around $11 \%$ compounded per annum. Rates outside Italy may have been slightly higher, with Heers finding that Genoese merchants in London charged 14-15\% per annum for straight loans and $15.5 \%$ to $18 \%$ on sales credits extended..$^{53}$ This compares to the implicit interest rates of $14.2 \%$ and $14.3 \%$ (compounded) per annum calculated from the spreads between the exchange rates in London and Bruges, and in London and Genoa respectively.

A more spiritually-sound use of capital was partnership investments in which the investor shared in the profits and the risks. In total, Datini invested around 26,000 florins in his six merchant banking companies and Melis has painstakingly reconstructed his returns on these investments. Overall, average returns on equity were consistent at $15-16 \%$ per annum, with the Genoese company slightly underperforming at $12.34 \% .{ }^{54}$ Such equity investments were not risk-free and the year-to-year returns could fluctuate significantly; the Catalan companies posted average annual returns of nearly $40 \%$ between 1396 and 1403 , peaking at $45.31 \%$ in $1398-9$, but falling to under $10 \%$ per annum after $1403 .{ }^{55}$ These figures may also overestimate the ex ante expected returns, since there is a significant survivorship bias as none of Datini's businesses failed and exposed him to significant capital losses. Still, the return from such investments was at least comparable to, and possibly slightly greater than, the implicit interest rates from exchange and rechange transactions. As a result, when Datini decided to invest 4,000 florins to establish a local banking company in Florence in 1398, one of his factors wrote to express his surprise, as 'most moneychangers tend to take up commerce and leave moneychanging, since they make more profit and also because it is more just in the eyes of God'. ${ }^{56}$

Of course, part of the profit generated by such companies would have come from their activities in the FX market, whether as genuine trade finance or 'dry exchange'. In terms

\footnotetext{
${ }^{51}$ Goldthwaite, 'Local banking', pp. 32-4.

${ }^{52}$ Edler de Roover, 'Restitution', pp. 778-85.

${ }^{53}$ Heers, 'Les Génois', pp. 816-18.

${ }^{54}$ Melis, Aspetti, p. 322.

${ }^{55}$ Melis, Aspetti, p. 271.

${ }^{56}$ Goldthwaite, Economy, p. 413.
} 
of direct industrial investment, between 1398 and 1406, the Strozzi wool company produced a return on equity of $17.6 \% .{ }^{57}$ Datini may have been less fortunate in his investments; although the veil manufacturing business he established with Domenico di Cambio returned $16.86 \%$ on his equity, his wool and dyeing businesses in Prato only made him 4-7\%. ${ }^{58}$ Implied interest rates have also been estimated from grain storage costs - estimated at between $12 \%$ and $20 \%$ - and wool forward contracts - equivalent to $17 \%-22 \%$ per annum. ${ }^{59}$

On the other hand, lending via bills of exchange or promised a higher return than investing in the monti of the Italian city-states. There is some controversy over how best to interpret the interest rates paid on this debt. The figures compiled by Epstein and used by Stasavage are based on the nominal coupons paid on the par value of the shares when issued. Between 1376 and 1425, shares in the Genoese public debt paid a coupon of 7-8\%, those of Venice around 4\%, and Florence between 3.75\% and 5\%. However, the limited data from the secondary market for such shares suggests that they subsequently traded at a considerable discount. During the period under study, the market price of Florentine debt fluctuated between $15 \%$ and $60 \%$ of par and that of Venice between $20 \%$ and $60 \% .^{60}$ As Chilosi has pointed out, using market yields rather than the par value of the coupon would almost double the actual interest rates charged to the city-states. ${ }^{61}$ It should also be noted that such investments were far from risk-free, given the frequent suspensions of interest payments. An alternative was to invest in urban or rural property but such long-term and secured investment is not strictly comparable to the extension of short-term and unsecured commercial credit. Clark calculates the annual return on land in Italy between 1350 and 1450 at $8.1 \%$ to $9.6 \%$. This seems high; the Florentine Catasto of 1427 capitalised rental income at 7\% and Pezzolo argues that income from land did not generally exceed $5 \%$ per annum. ${ }^{62}$

To summarise, the returns from engaging in exchange and rechange transactions were higher than investing in 'safe' assets such as landed property or shares in the debt of Italian city-states, and comparable to or only slightly lower than equity investment in trading and industrial ventures. This seems to be in line with the risk involved in these different investments. As a result, it seems that Domenico di Cambio, Datini's partner at Florence, may have slightly over-estimated the profitability of such FX transactions compared to other activities when he asserted that 'I would rather earn $12 \%$ with our merchandise than $18 \%$ on exchange dealings'. ${ }^{63}$ However, here Domenico was primarily asserting a moral position based on the association of some types of FX transactions with usury.

\section{V.}

A major strand in the historiography of medieval finance has argued that the bill of exchange was frequently or even primarily used to circumvent the church prohibition on charging

\footnotetext{
${ }^{57}$ Goldthwaite, Private Wealth, pp. 39-42.

${ }^{58}$ Melis, Aspetti, p. 322.

${ }^{59}$ Brunt and Cannon, 'Grain of truth'; McCloskey and Nash, 'Corn at interest', pp. 178-85; Bell at al. English Wool Market, pp. 139-43.

${ }^{60}$ Epstein, Freedom, pp. 18-19 n. 18; Stasavage, States of Credit, p. 38; Pezzolo, 'Bonds', pp. 154, 157.

${ }^{61}$ Chilosi, 'Risky institutions', pp. 890-2.

${ }^{62}$ Clark, 'Cost of capital, pp. 274-5; Goldthwaite, Economy, p. 566; Pezzolo, 'Bonds', p. 160. For the low rates of return on land, see also Goldthwaite, Private Wealth, pp. 246-50.

${ }^{63}$ Origo, Merchant of Prato, p. 147.
} 
interest, in part because there was no fixed or certain profit. Our results show that, although the average interest rates were consistent across the different exchange rate pairs, there was still a very considerable degree of uncertainty regarding the returns from any particular exchange and rechange transaction. Just as today, investing in the FX market could be risky. Some indications of the risk involved in such transactions are shown in Table 5.

\section{Table 5: Risk and return}

\begin{tabular}{|c|c|c|c|c|c|c|c|}
\hline \multirow{2}{*}{$\begin{array}{l}\text { City } \\
\text { From }\end{array}$} & \multirow[t]{2}{*}{ City To } & \multirow{2}{*}{$\begin{array}{l}\text { Negative } \\
\text { return }\end{array}$} & \multicolumn{2}{|c|}{ Spread } & \multicolumn{2}{|c|}{ APR compounded } & \multirow{2}{*}{$\begin{array}{l}\text { Sharpe } \\
\text { ratio }\end{array}$} \\
\hline & & & Mean & STDEV & Mean & STDEV & \\
\hline Barcelona & Bruges & $5.64 \%$ & $4.40 \%$ & $3.52 \%$ & $14.42 \%$ & $7.16 \%$ & 0.896 \\
\hline Barcelona & Florence & $6.12 \%$ & $3.93 \%$ & $2.90 \%$ & $12.73 \%$ & $5.60 \%$ & 0.844 \\
\hline Barcelona & Genoa & $9.46 \%$ & $3.33 \%$ & $2.77 \%$ & $16.79 \%$ & $6.75 \%$ & 1.301 \\
\hline Barcelona & Venice & $2.45 \%$ & $4.43 \%$ & $2.60 \%$ & $14.31 \%$ & $4.97 \%$ & 1.268 \\
\hline Bruges & Barcelona & $6.10 \%$ & $4.50 \%$ & $3.21 \%$ & $14.67 \%$ & $6.22 \%$ & 1.073 \\
\hline Bruges & Genoa & $10.09 \%$ & $3.73 \%$ & $3.26 \%$ & $15.93 \%$ & $7.36 \%$ & 1.077 \\
\hline Bruges & London & $8.94 \%$ & $2.24 \%$ & $2.06 \%$ & $15.20 \%$ & $6.04 \%$ & 1.191 \\
\hline Bruges & Paris & $13.9 \%$ & $1.33 \%$ & $1.27 \%$ & $11.53 \%$ & $3.96 \%$ & 0.893 \\
\hline Bruges & Venice & $8.00 \%$ & $3.68 \%$ & $2.60 \%$ & $11.82 \%$ & $4.91 \%$ & 0.779 \\
\hline Florence & Barcelona & $4.58 \%$ & $3.85 \%$ & $2.52 \%$ & $12.37 \%$ & $4.83 \%$ & 0.905 \\
\hline Florence & Genoa & $10.80 \%$ & $0.83 \%$ & $0.89 \%$ & $12.10 \%$ & $3.88 \%$ & 1.056 \\
\hline Florence & Venice & $9.74 \%$ & $0.82 \%$ & $0.74 \%$ & $10.91 \%$ & $2.92 \%$ & 0.998 \\
\hline Genoa & Barcelona & $7.55 \%$ & $3.48 \%$ & $2.76 \%$ & $17.59 \%$ & $7.03 \%$ & 1.364 \\
\hline Genoa & Bruges & $1.97 \%$ & $3.52 \%$ & $2.20 \%$ & $14.67 \%$ & $4.93 \%$ & 1.353 \\
\hline Genoa & Florence & $10.57 \%$ & $0.84 \%$ & $0.88 \%$ & $12.17 \%$ & $3.67 \%$ & 1.135 \\
\hline Genoa & London & $4.49 \%$ & $6.85 \%$ & $3.87 \%$ & $14.54 \%$ & $5.87 \%$ & 1.114 \\
\hline Genoa & Paris & $0.78 \%$ & $3.81 \%$ & $1.89 \%$ & $17.05 \%$ & $4.39 \%$ & 2.060 \\
\hline Genoa & Venice & $8.55 \%$ & $1.45 \%$ & $1.24 \%$ & $11.44 \%$ & $3.71 \%$ & 0.926 \\
\hline London & Bruges & $8.66 \%$ & $2.11 \%$ & $2.11 \%$ & $14.30 \%$ & $6.14 \%$ & 1.027 \\
\hline London & Genoa & $1.20 \%$ & $6.67 \%$ & $4.46 \%$ & $14.20 \%$ & $6.87 \%$ & 0.901 \\
\hline Paris & Bruges & $7.89 \%$ & $1.15 \%$ & $0.93 \%$ & $9.72 \%$ & $2.92 \%$ & 0.588 \\
\hline Paris & Genoa & $7.40 \%$ & $3.39 \%$ & $2.72 \%$ & $15.37 \%$ & $6.39 \%$ & 1.152 \\
\hline Paris & Venice & $3.47 \%$ & $4.26 \%$ & $2.70 \%$ & $13.77 \%$ & $5.25 \%$ & 1.100 \\
\hline Venice & Barcelona & $2.06 \%$ & $4.28 \%$ & $2.67 \%$ & $13.81 \%$ & $5.11 \%$ & 1.138 \\
\hline Venice & Bruges & $8.80 \%$ & $3.38 \%$ & $2.62 \%$ & $10.85 \%$ & $4.92 \%$ & 0.578 \\
\hline Venice & Florence & $18.47 \%$ & $0.79 \%$ & $1.05 \%$ & $10.89 \%$ & $4.21 \%$ & 0.687 \\
\hline Venice & Genoa & $18.99 \%$ & $1.32 \%$ & $1.72 \%$ & $10.78 \%$ & $5.35 \%$ & 0.520 \\
\hline Venice & Paris & $3.63 \%$ & $4.14 \%$ & $2.61 \%$ & $13.34 \%$ & $4.99 \%$ & 1.070 \\
\hline
\end{tabular}

Source: Exchange Rate Dataset. 
First of all, it was certainly possible for the lender to lose money on an exchange and rechange transaction. In the case of cambium ad Venetias examined above, some $9.4 \%$ of the transactions originating at Florence ( 81 of 832 ) and $18.5 \%$ of those at Venice (142 of 769) would have produced a negative return. This discrepancy partly reflects the shorter usance from Florence to Venice as opposed to Venice to Florence. On the other hand, only $1.20 \%$ of the exchange and rechange transactions from London to Genoa resulted in a negative return. This was an inevitable consequence of the way that the system operated. Because the combined usance period between Florence and Venice was only 30 days, the spread required to produce a reasonable interest rate was less than one per cent. Thus relatively small movements in the rates at Florence and Venice could wipe out this spread. As an exchange and rechange transaction between Genoa and London took six times as long, the spread was roughly six times the size and it was much less likely that the fluctuations in exchange rates would exceed this.

Another way of measuring risk is to examine the standard deviation of the returns rather than just the mean. Table 5 first shows the standard deviations in the spreads between the rates. This seems to throw up some odd results as the short-term return between Genoa and Florence was more volatile (mean of $0.84 \%$ and a standard deviation of $0.88 \%$ ) than the long-term return between Genoa and London (6.82\% and 3.56\% respectively). However, this does not take into account the frequency of transactions. A merchant could carry out six exchange and rechange operations between Genoa and Florence in the same time as one between Genoa and London. The annual return from trading Florence-Genoa would be the product of twelve separate transactions, rather than two in the case of Genoa-London. A greater number of operations per year is statistically likely to smooth out the standard deviation of the expected annual return.

Thus we calculate adjusted standard deviations taking into account the number of operations possible in each year. We treat the sample as a population, which we are effectively drawing from. Supposing that there are 100 observations which have a mean of $x$ and a variance of $y$. We treat this as the population and then standard sampling theory applies so if a set of $N$ observations is drawn from the population, it will be normally distributed with the same mean $(x)$ and a variance of $y / N$, and the standard deviation of the sample will be the square root of $(y / N)$, where $N$ is the number drawn from the "population" (not how many observations there were originally).

These adjusted standard deviations are also shown in table 5. Returning to the above example of Genoa-Florence and Genoa-London, for the former, the unadjusted standard deviation of the compounded annual returns is $13.27 \%$ but, taking into account the number of transactions, the adjusted standard deviation falls to $3.67 \%$. This can then be compared to the mean compounded annual value of $12.14 \%$. For the latter, the adjustment to the standard deviation is naturally smaller, from $8.25 \%$ to $5.80 \%$, compared to the mean of $13.89 \%$. This adjustment seems to resolve the counter-intuitive finding that returns on short-term credit were more volatile and risky than those on longer-term credit arrangements. It also highlights further examples of differences depending on the direction of the transaction. For instance, the adjusted standard deviation of returns from Florence to Venice is $2.89 \%$ (the lowest of any, commensurate with the idea that this was the most developed market) but from Venice to Florence it is $4.21 \%$. A similar situation applies to Genoa and Bruges/Paris, and Paris-Bruges, reflecting the asymmetry in the usance periods. 
We can now use the adjusted standard deviations to assess the risk-adjusted returns of exchange and rechange transactions for different currency pairs and directions. A standard method to assess risk-weighted returns is the Sharpe ratio. ${ }^{64}$ This measures the excess return (or risk premium) per unit of deviation produced by an investment asset or a trading strategy. The Sharpe ratio is calculated by deducting a benchmark rate from the mean return, and then dividing by the standard deviation. A higher Sharpe ratio promises better return for the same risk or, viewed from the opposite perspective, the same return for lower risk. We use a figure of $8 \%$ as a reasonable return for a term deposit a discrezione with a merchant society, which is the most natural alternative form of short-term credit to the use of bills of exchange.

The risk-adjusted returns are very consistent across all the currency pairs as most of the Sharpe ratios cluster around one. Again, the asymmetry observed above for FlorenceVenice as opposed to Venice-Florence is evident, as the former offers a much better return per unit of deviation than the latter (1.00 compared to 0.68$)$. The same holds for transactions from Genoa to Bruges/Paris as opposed to the reverse. These figures bear close resemblance to their modern counterparts - for example, Lo calculates annual Sharpe ratios of between 0.5 and 1.2 for a set of US mutual fund returns over periods of varying length ending in $2000 .{ }^{65}$ This analysis shows that there was a considerable degree of risk involved in such transactions and so merchants engaging in exchange and rechange could legitimately argue that they were not usurious as their profits were not certain or fixed in advance.

In general, moderate levels of interest seem to have been accepted by the secular courts. The Venetian courts would enforce the collection of interest at moderate rates of 5$12 \%$ per annum and English common law courts would award damages for late payment at a similar rate. ${ }^{66}$ The relatively rare examples of usury prosecutions tended to be short-lived and often politically-motivated. ${ }^{67}$ Most dramatically, in 1429, Florence banned dry exchange (cambium sine litteris). However, in 1435 this was suspended, initially for two years and it does not seem to have been revived subsequently. In any case, the Medici account books show that they were still engaging in such transactions in $1433 .^{68}$

Whether this element of risk alone was sufficient to absolve merchants from the sin of usury is still debatable. Datini himself expressed ethical concerns, particularly as he grew older and more concerned with his ultimate fate. His friend, the Florentine notary Ser Lapo di Mazzei, warned him that 'these exchanges, which you make at hazard, without any letter or coins, are as bad as playing at dice'. Simone d'Andrea, head of Datini's branch in Barcelona, was the chief offender. In 1400, Datini wrote to him repeating a prohibition on such dealings, stating that 'once for all, I would have you a merchant and not a banker', and this criticism was repeated in 1402 and $1406 .{ }^{69}$ However, at the same time as he was castigating d'Andrea, Datini himself employed similar exchange and rechange transactions to lend money to a neighbour and to the heirs of a former business partner. In the latter case, he was criticised by one of his correspondents that it would have been cheaper to have borrowed by accepting a

\footnotetext{
${ }^{64}$ This method is also used in Booth, 'Foreign exchange profits', pp. 137-8.

${ }^{65}$ Lo, 'Sharpe ratios'.

${ }^{66}$ Lane, 'Investment and usury', p. 63; Brand, 'Aspects', p. 33.

${ }^{67}$ Seabourne, 'Controlling commercial morality', pp. 124-7; Bratchel, 'Usury', pp. 256-7.

${ }^{68}$ De Roover, Rise and Decline, pp. 135, 433 n. 57.

${ }^{69}$ Origo, Merchant of Prato, pp. 152-3.
} 
term deposit a discrezione.$^{70}$ Even the virtuous Mazzei asked Datini to withdraw money for him from a deposit issued by the Florentine wool gild at $8-10 \% .^{71}$

\section{VI.}

Overall, we argue that the use of exchange rates to calculate implicit interest rates is a valuable tool. First, it dramatically increases the number of interest rate observations available to the medieval historian. Second, it proves that interest rates were indeed incorporated into exchange rates in a systematic way. Third, it also paints a consistent picture of commercial interest rates at between 10 and $16 \%$, which are comparable to the more scattered indications of returns on other forms of investment. Fourth, there was a high degree of variation in returns, which were not infrequently negative - the risk involved may have helped to justify the non-usurious nature of these transactions, although theologians and some merchants still had doubts.

This raises a question - why use bills of exchange as credit instruments if they were remained of questionable virtue and other, more straightforward, forms of charging interest were generally tolerated? In fact, when it came to their day-to-day business affairs, Florentine merchants seem to have employed their capital in undoubtedly 'legitimate' purposes such as trade or genuine transfers of funds using bills of exchange, while at the same time investing in more controversial instruments such as dry exchange, time deposits a discrezione, government debt and discounting for sales on credit. $^{72}$ Such decisions were probably driven more by business considerations than moral ones. For instance, merchant manuals and books of advice stressed the importance of diversification as an investment strategy. ${ }^{73}$ In fact, as we have seen, the rates of return on all these classes of investment were broadly comparable. If the usury prohibition was, at least for this class of merchant, a dead letter, were there other reasons for using FX transactions in this way?

In fact, the extension of credit via exchange and rechange transactions did offer a number of advantages. ${ }^{74}$ First, it was extremely flexible. The variety of different currency pairs and usance periods between different cities made it possible to construct loans of varying lengths while exchange transactions could be rolled over an indefinite number of times by agreement. The best-documented are the short-term one month loans between Florence and Venice. By contrast, demand deposits did not usually pay interest while most time deposits were for six months or one year. At the same time, the use of FX transactions offered the lender slightly higher returns (for an acceptable degree of additional risk). They may be considered the medieval equivalent of money market funds. From a broader perspective, the FX market was of vital importance for medieval trade and economic activity. As we have seen, not all exchange transactions were used to create loans. If there were no local borrowers then the lender could buy a 'genuine' trading bill from merchants wishing to make actual transfers of funds for business purposes. Equally, a merchant seeking to fund his trading could transact with one of these financial 'speculators' rather than having to find a

\footnotetext{
${ }^{70}$ Mueller, Venetian Money Market, pp. 323-5.

${ }^{71}$ Trexler, Public Life, pp. 136-7.

${ }^{72}$ See de Roover, Rise and Fall, pp. 236-8.

${ }^{73}$ See Bernardo Cotrugli's advice quoted in Lopez and Raymond, eds., Medieval Trade, p. 414.

${ }^{74}$ Mueller, Venetian Money Market, p. 290.
} 
counterparty wishing to transfer money in the opposite direction. One of the major difficulties facing early capital markets was ensuring sufficient 'thickness' and combining the FX and credit markets may have increased liquidity in both. ${ }^{75}$

Looking forward, the compilation of a larger and more internally consistent dataset of FX and interest rates will hopefully facilitate the use of more sophisticated quantitative methods to supplement the more qualitative evidence provided by other sources.

\section{Footnote References}

Bell, A.R., Brooks, C., and Dryburgh, P., The English Wool Market, c.1230-1327 (Cambridge, 2007).

Bell, A.R., Brooks, C., and Moore, T.K., 'Interest in medieval accounts: examples from England, 1272-1340'. History, 94 (2009), pp. 411-33.

Bell, A.R., Brooks, C., and Moore, T.K., 'Medieval foreign exchange: A time series analysis', in M. Casson and N. Hashimzade, eds., Large Databases in Economic History: Research Methods and Case Studies (Aldershot, 2013), pp. 97-123.

Bell, A.R., Brooks, C., and Moore, T.K., 'The seasonality of foreign exchange and interest rates in late medieval Europe', European Historical Economics Society Conference 2015. Available online at: http://www.ehes.org/ehes2015/papers/Bell_Brooks_Moore.pdf. Accessed on 14 December 2015.

Bell, A.R. and Sutcliffe, C., 'Valuing medieval annuities: Were corrodies underpriced?' Explorations in Economic History 47 (2010), pp. 142-157.

Benson, L.D., ed., The Riverside Chaucer. ( $3^{\text {rd }}$ ed., Oxford, 1987).

Bolton, J.L. and Guidi Bruscoli, F., 'The Borromei bank research project', in L. Armstrong, I. Elbl and M.M. Elbl, eds., Money, Markets and Trade in Late Medieval Europe: Essays in Honour of John H. A. Munro (Leiden, 2007), pp. 460-88.

Booth, G.G., 'Foreign exchange profits in two early Renaissance money markets', Journal of European Economic History, 38 (2009), pp. 123-144.

Borlandi, A., ed., Il Manuale di Mercantura di Saminiato de' Ricci (Genoa, 1963).

Borlandi, F., ed., E Libro di Mercatantie et Usanze de' Paesi (Torino, 1936).

Brand, P.A., 'Aspects of the Law of Debt, 1189-1307', in P.R. Schofield and N.J. Mayhew, eds., Credit and Debt in Medieval England, c.1180-c.1350 (Oxford, 2002), pp. 19-41.

Bratchel, M.E., 'Usury in the fifteenth-century Lucchesia: Images of the petty moneylender'. Journal of European Economic History, 32 (2003), pp. 249-76.

Briggs, C.D., Credit and Village Society in Fourteenth-Century England (Oxford, 2009).

Brunt, L. and Cannon, E., 'A grain of truth in medieval interest rates? Re-examining the McCloskey-Nash hypothesis', University of Bristol Working paper 14 (1999). Available online at: http://www.efm.bris.ac.uk/ecesc/Articles/mn.pdf. Accessed on 5 December 2014.

\footnotetext{
${ }^{75}$ Van Zanden et al., 'Small is beautiful', p. 4.
} 
Calendar of State Papers Relating to English Affairs in the State Archives of Venice: volume 2, 1509-19 (London, 1867).

Chilosi, D., 'Risky institutions: political regimes and the cost of public borrowing in early modern Italy', Journal of Economic History, 74 (2014), pp. 887-915.

Chilosi, D. and Volckart, O., 'Money, states and empire: financial integration and institutional change in central Europe, 1400-1520', Journal of Economic History, 71 (2011), pp. 762-791.

Clark, G., 'The cost of capital and medieval economic technique', Explorations in Economic History, 25 (1988), pp. 265-94.

Edler de Roover, F., 'Restitution in Renaissance Florence', in Studi in Onore di Armando Sapori (2 vols., Milan, 1957), II, pp. 775-89.

Einzig, P., The History of Foreign Exchange (2 ${ }^{\text {nd }}$ ed., London, 1970).

d'Emic, M.T., Justice in the Marketplace in Early Modern Spain: Saravia, Villalon and the Religious Origins of Economic Analysis (Lanham, 2014)

Epstein, S.R., Freedom and Growth: the Rise of States and Markets in Europe, 1300-1750 (London, 2000).

Fratianni, M. and Spinelli, F., 'Italian city-states and financial evolution', European Review of Economic History, 10 (2006), pp. 257-78.

Goldthwaite, R.A., Private wealth in Renaissance Florence: A Study of Four Families. (Princeton NJ, 1968).

Golthwaite, R.A., 'Local banking in Renaissance Florence', Journal of European Economic History, 14 (1985), pp. 5-55.

Goldthwaite, R.A., The Economy of Renaissance Florence (Baltimore, 2009).

Heers, J., 'Les Génois en Angleterre: La crise de 1458-1466', in Studi in Onore di Armando Sapori (2 vols., Milan, 1957), II, pp. 809-32.

Heers, J., Gênes au XV Siècle: Activité Économique et Problèmes Sociaux (Paris, 1961).

Homer, S. and Sylla, R., A History of Interest Rates ( ${ }^{\text {th }}$ ed., Hoboken, NJ, 2005).

Koyama, M., 'Evading the 'taint of usury': the usury prohibition as a barrier to entry', Explorations in Economic History, 47 (2010), pp. 420-42.

Kugler, P., 'Financial market integration in late medieval Europe: Results from a Threshold Error Correction model for the Rhinegulden and Basle Pound, 1365-1429', Swiss Journal of Economics and Statistics, 147 (2011), pp. 337-57

Lane, F.C., 'Investment and usury', in Venice and History: The Collected Papers of Frederic C. Lane (Baltimore, 1966), pp. 56-68.

Leone, A., 'Some preliminary remarks on the study of foreign currency exchange in the medieval period', Journal of European Economic History, 12 (1983), pp. 619-629.

Li, L.-F., 'Bullion, bills and arbitrage: Exchange markets in fourteenth- to seventeenth century Europe (unpublished London School of Economics PhD thesis, 2012).

Lo, A., 'The statistics of Sharpe ratios', Financial Analysts Journal, 58 (2002), pp. 36-52. 
Lopez, R.S. and Raymond, I.W., eds., Medieval Trade in the Mediterranean World: Illustrative Documents (New York, 1967).

Mandich, G., 'Per una ricostruzione delle operazioni mercantili e bancarie della compagnia Covoni', in A. Sapori,ed., Libro Giallo della Compagnia dei Covoni (Milan, 1970), pp. xcixccxiii.

McCloskey, D.N. and Nash, J., 'Corn at interest: the extent and cost of grain storage in medieval England', American Economic Review, 74 (1984), pp. 174-187.

McCusker, J.J. and Gravesteijn, C., The Beginnings of Commercial and Financial Journalism: the Commodity Price Currents, Exchange Rate Currents, and Money Currents of Early Modern Europe (Amsterdam, 1991).

Melis, F., Aspetti della Vita Economica Medievale: Studi nell'Archivio Datini di Prato. (Siena, 1962).

Melis, F., 'Intensità e regolarità nella diffusione dell'informazione economica generale nel Mediterraneo e in occidente alla fine del medioevo', in L. Frangioni, ed., I Trasporti e le Comunicazioni nel Medioevo con Introduzione di Michel Mollat (Florence, 1985), pp. 179223.

Mueller, R.C., The Venetian Money Market: Banks, Panics, and the Public Debt, 1200-1500 (Baltimore, 1997).

Nigro, G., ed., Francesco di Marco Datini: The Man, the Merchant (Florence, 2010).

Noonan, J.T., The Scholastic Analysis of Usury (Cambridge, MA, 1957).

Origo, I., The Merchant of Prato: Francesco di Marco Datini, 1335-1410 (London, 1957).

Pagnini, G., ed., Della Decima e di Varie Altre Gravezze Imposte dal Comune di Firenze della Monete e della Mercatura de Fiorentini Fino al Secolo XVI (4 vols, Lisbon-Lucca, 1765-6).

Pezzolo, L., 'Bonds and government debt in Italian city states, 1250-1650', in W.N. Goetzmann and K.G. Rouwenhorst, eds., The Origins of Value: The Financial Innovations that Created Modern Capital Markets (Oxford, 2005), pp. 145-163.

Postan, M.M., 'Credit in medieval trade' Economic History Review, I (1928), pp. 234-61.

de Roover, R.A., Money, Banking and Credit in Mediaeval Bruges: Italian MerchantBankers, Lombards and Moneychangers, a Study in the Origins of Banking (Cambridge, MA, 1948).

de Roover, R.A., 'Cambium ad Venetias: Contribution to the history of foreign exchange', in Studi in Onore di Armando Sapori (2 vols., Milan, 1957), I, pp. 631-58.

de Roover, R.A., The Rise and Decline of the Medici Bank, 1397-1494 (Cambridge MA, 1966).

de Roover, R.A., 'The scholastics, usury, and foreign exchange', Business History Review, 41 (1967), pp. 257-71.

de Roover, R.A., The Bruges Money Market Around 1400 with a Statistical Supplement by Hyman Sardy (Brussels, 1968). 
Rubin, J., 'Bills of exchange, interest bans and impersonal exchange in Islam and Christianity', Explorations in Economic History, 47 (2010), pp. 213-27.

Seabourne, G., 'Controlling commercial morality in late medieval London: The usury trials of 1421', Journal of Legal History, 19 (1998), pp. 116-142.

Spufford, P.R., Handbook of Medieval Exchange (London, 1986).

Stasavage, D., States of Credit: Size, Power and the Development of European Polities (Princeton, NJ, 2011).

Trexler, R.C., Public Life in Renaissance Florence (New York, 1980).

Van Zanden, J.L., Zuijverduin, C.J., and de Moor, T., 'Small is beautiful: the efficiency of credit markets in the late medieval Holland', European Review of Economic History, 16 (2012), pp. 3-22.

Wood, D., Medieval Economic Thought (Cambridge, 2002).

Zuijderduijn, C.J., Medieval Capital Markets: Markets for Renten, State Formation and Private Investment in Holland, 1300-1550 (Leiden, 2009). 